
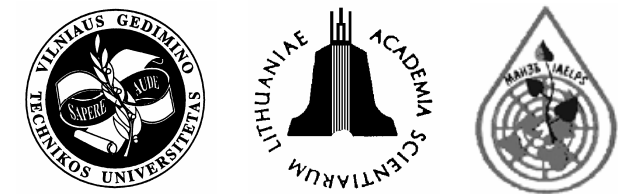

\title{
NATURAL RADIONUCLIDE DISTRIBUTION AND RADON EXHALATION RATE FROM THE SOIL IN VILNIUS CITY
}

\author{
Dainius Jasaitis, Aloyzas Girgždys \\ Laboratory of Nuclear Hydrophysics, Vilnius Gediminas Technical University, \\ Sauletekio al. 11, LT-10223 Vilnius, Lithuania.E-mail:algi@fm.vtu.lt \\ Submitted 10 Oct 2006; accepted 15 Dec 2006
}

\begin{abstract}
In the territory of Vilnius city radioisotopic composition of different soils was experimentally determined and radon exhalation rate from the soil was evaluated using these data. Specific activitys of natural radionuclides ${ }^{226} \mathrm{Ra},{ }^{232} \mathrm{Th}$ and ${ }^{40} \mathrm{~K}$ were measured. From identified natural radionuclides the biggest quantities were for ${ }^{40} \mathrm{~K}(263 \mathrm{~Bq} / \mathrm{kg})$, the smallest values - for ${ }^{232} \mathrm{Th}(5 \mathrm{~Bq} / \mathrm{kg})$, average ${ }^{226} \mathrm{Ra}$ values reached $13 \mathrm{~Bq} / \mathrm{kg}$. Radon exhalation rate from the soil in Vilnius city was calculated and evaluated. Distribution of radon exhalation rate values in the whole territory of the city is stated. The received values vary from $15 \mathrm{~Bq} / \mathrm{m}^{2} \cdot \mathrm{h}$ (in clay loam) to $23 \mathrm{~Bq} / \mathrm{m}^{2} \cdot \mathrm{h}$ (in sand). It is assessed that of the most important parameters, which determine radon exhalation rate from the soil, are the quantity of radium and the porosity of the soil. It is observed that radon exhalation rate from the soil is bigger than that from building materials. This difference is determined by a bigger porosity of the soil.
\end{abstract}

Keywords: natural radionuclides, specific activity, radon, exhalation rate, volumetric activity, alpha particles.

\section{Introduction}

Recently attention paid to artificial radionuclides has been very conspicuous, whereas attention paid to radionuclides of a natural origin has been less, though it is known that the contribution of artificial radionuclides in our environment is much smaller. Natural radionuclides in the soil generate a significant component of the background radiation exposure of the population [1]. Natural radionuclides in the soil are sources of external and internal radiation exposure in dwellings.

Equivalent dose rate caused by radiation of soil radionuclides directly depends on their specific activity in the soil. A significant part of the dose contribution in the form of natural sources comes from terrestrial gamma radionuclides [2]. The most widely spread radionuclides of a natural origin are from uranium $\left({ }^{238} \mathrm{U}\right)$, thorium $\left({ }^{232} \mathrm{Th}\right)$ and actinium $\left({ }^{235} \mathrm{Ac}\right)$ families as well as potassium $\left({ }^{40} \mathrm{~K}\right)$. The exposure of the population from natural sources depends on natural radionuclides found underground the quantities of which differ due to the soil composition. The distribution of radionuclides in the soil has been very widely explored, yet the quantative evaluation of their activity is frequently ambiguous, and this is because of the soil being a complicated component of the nature system.

Internal exposure is caused by radon $\left({ }^{222} \mathrm{Rn}\right)$ - natural radioactive gas - exhalation from materials. Mostly irradiance dose is influenced by short-term products of radon decay $-{ }^{218} \mathrm{Po},{ }^{214} \mathrm{~Pb},{ }^{214} \mathrm{Bi},{ }^{214} \mathrm{Po}$, etc $[3,4]$. Their ionization power is 20 times higher than beta and gamma rays [5]. According to scientists, radon might cause cancer if it's in a dwelling-place [6]. When this gas decays in human airway, alpha particles may damage cells and cause cancer.

Radon appears when radium $\left({ }^{226} \mathrm{Ra}\right)-{ }^{238} \mathrm{U}$-family division product - splits up. In many countries the most important source of radon is the ground, however, it is possible that radon's volumetric activity indoors is determined by building materials, water-supply [7, 8].

There are two stages in studying radon diffusion: its emission through pores of a solid material and its carry by air outwards [9]. When radon gets to air, gas diffuses in the atmosphere, and then, after getting into an enclosed space (house or other building), dangerous concentration might occur [10]. Radon's way to an accommodation is various: it penetrates from ground through the underpinning and floor, exhalates from building materials, water, burning gas, etc (Fig 1).

In Lithuania, like in many countries, the main source of radon in the environment is its flux from the ground, therefore, the volumetric activity of radon indoors is determined by the construction and geometry of an accommodation [11].

Radon gas is one of the main sources of radiation in the environment. Many other natural and unnatural sources of radiation are many times lesser [12].

The intensity of natural radiation and caused exposure depends on a geological and geographical environment, that is why in various regions it is different [2]. 


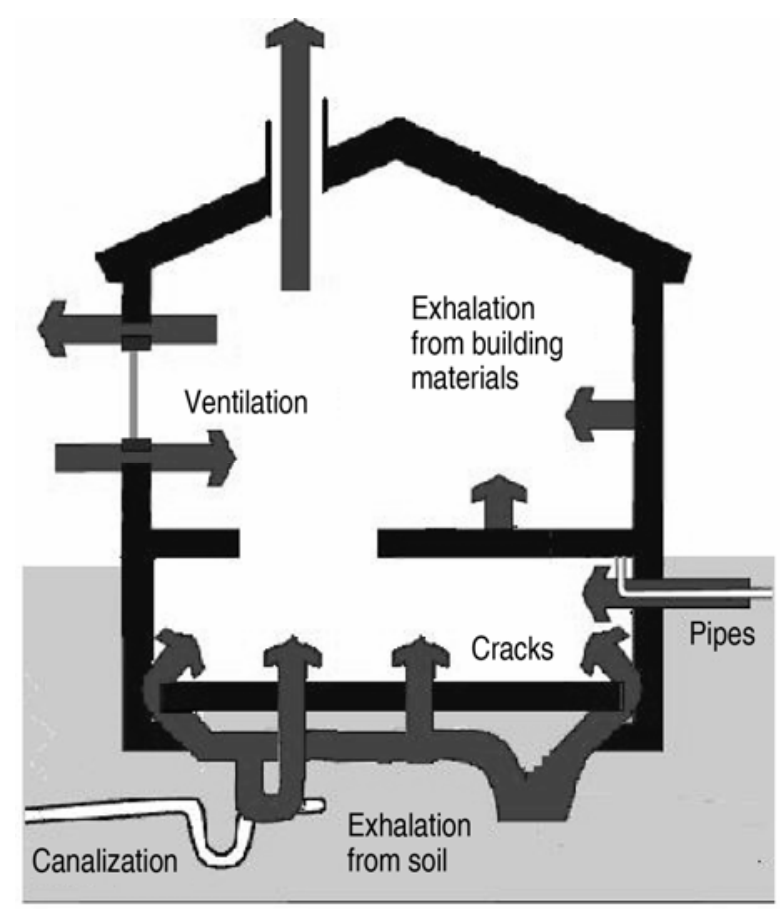

Fig 1. Radon entry routes in houses

The aims of this investigation are: to estimate the radioisotopic composition in different types of the soil in Vilnius city; to measure the specific activity of natural radionuclides ${ }^{226} \mathrm{Ra},{ }^{232} \mathrm{Th}$ and ${ }^{40} \mathrm{~K}$ found in samples of a different granulemetric composition; to evaluate radon exhalation rate from the soil.

\section{Investigation methodology}

Soil samples were taken in southern, western, northern and central parts of Vilnius city and divided into 3 groups according to the type of soil - sand, sandy loam, clay loam. 72 samples from the surface layer of the soil (depth of 0-5 cm) were taken for the investigation.

A metal ring with a diameter of $150 \mathrm{~mm}$ and a height of $50 \mathrm{~mm}$ was used to take the soil, it was hammered into the ground, and the ground from the bottom was lifted up with a spade. The samples were transported in plastic bags to a laboratory. Then they were weighed and placed into vessels of $200 \mathrm{ml}$ capacity in the laboratory. Dry soil was granulated, sieved out and poured into a measuring vessel and weighed.

To identify the specific activity of natural radionuclides in the soil, the activity of the samples was measured by a gamma spectrometric system (CANBERRA) together with a semiconductor HPGe detector (with resolution of $2 \mathrm{keV}$, efficiency of $15 \%$ ). The detector's sensor is of a big differential power as it is constantly freezed with liquid nitrogen. The spectrometer was calibrated for the vessel of $200 \mathrm{ml}$ capacity. Solid ${ }^{152} \mathrm{Eu}+{ }^{137} \mathrm{Cs}$ standards of definite activity of different densities were used for calibration.

The specific activity of the main gamma emitters in the soil was identified using exposures of 24-72 hour sample measurements. The radionuclides were identified according to the following energy lines: ${ }^{226} \mathrm{Ra}-186 \mathrm{keV}$,
${ }^{208} \mathrm{Tl}-583 \mathrm{keV},{ }^{137} \mathrm{Cs}-662 \mathrm{keV},{ }^{40} \mathrm{~K}-1460 \mathrm{keV} .{ }^{208} \mathrm{Tl}$ is a product of decay of $232 \mathrm{Th}$, that is why their ratio of specific activity was taken equal to 1,6 , and it was respectively calculated [13].

The specific activity of the radionuclides was recalculated according to the formula:

$$
A=\left(\frac{S}{t}-\frac{S_{f}}{t_{f}}\right) / m \cdot \varepsilon \cdot \eta,
$$

where $S$ - area of the peak of measured radionuclide material, (imp/s); $S_{f}$ - area of the peak of background radiation (imp/s); $t$ - sample measuring time (s); $\varepsilon$ - product of energetic and geometric efficiency of a semiconductor spectrometer; $\eta$ - quantum output of radionuclide decay; $m$ - mass of a measured sample $(\mathrm{kg})$.

In the course of measurements the background of gamma radiation was periodically measured. Its level in the course of measurements was more or less steady. The exposures of the measured samples were selected so that the changes of the background would not make up more than $4 \%$ of the size of their signal.

Since the influence of most meteorological parameters on advection is usually temporary, instantaneous and difficult to be modeled $[14,15]$, only diffusion mechanism is considered in this work for estimating average long-term values. Based on the conservation of mass, an idealized, one-dimensional, steadystate model for the transportation and distribution of radon in the soil can be expressed as the following differential equation [16]:

$$
D_{e} \frac{d^{2} C}{d x^{2}}-\lambda C+\frac{A}{p_{e f}}=0,
$$

where $D_{e}$ is the effective radon diffusion coefficient $\left(\mathrm{m}^{-2} \mathrm{~s}^{-1}\right) ; C$ represents the radon concentration in pore air of the soil $\left(\mathrm{Bq} \mathrm{m}^{-3}\right) ; x$ is a distance from the ground surface with its positive direction downward $(\mathrm{m}) ; \lambda$ is the radon decay constant $\left(\mathrm{s}^{-1}\right) ; p_{\text {ef }}$ is the effective porosity of the soil; $A$ defined as Eq 3 is the production rate of radon gas into the pore space:

$$
A=\lambda \rho R E
$$

where $\rho$ is the dry bulk density of the soil $\left(\mathrm{kg} \cdot \mathrm{m}^{-3}\right)$; $R$ is ${ }^{226} \mathrm{Ra}$ activity concentration in the soil particles $\left(\mathrm{Bq} \mathrm{kg}^{-1}\right) ; E$ is the radon emanation coefficient.

Given the boundary conditions when $\left.C\right|_{x=0}=C_{0}$ and $\left.C\right|_{x \rightarrow \infty}$ is finite, the solution for Eq 2 is:

$$
C=\frac{A}{\lambda p_{e f}}\left[1-\exp \left(-\frac{\sqrt{\lambda D_{e}}}{D_{e}} x\right)\right] .
$$

On the other hand, as radon flux is continuous at the ground surface between the soil and atmosphere, the exhalation rate $(\mathrm{F})$ of radon from the ground surface can be expressed as follows:

$$
F=\left.p_{e f} D_{e} \frac{d C}{d x}\right|_{x=0} .
$$

Combined with Eq 4, Eq 5 can be rewritten as

$$
F=\sqrt{\lambda D_{e}} \rho E R \text {. }
$$


It is known that the effective radon diffusion coefficient $\left(D_{e}\right)$ in the soil has been experimentally studied, which can be expressed as the following equation [17]:

$$
D_{e}=p D_{0} \exp \left(-6 m p-6 m^{14 p}\right) \text {, }
$$

where $p$ is the total soil porosity which can be estimated by Eq $8[18] ; D_{0}$ is the radon diffusion coefficient in open air with a constant of $1.1 \cdot 10^{-5} \mathrm{~m}^{2} \mathrm{~s}^{-1} ; m$ is the volume fraction of water saturation which can be calculated from water mass content $(w)$ by using Eq 9:

$$
\begin{gathered}
p=(93.947-32.995 \rho) / 100, \\
m=\omega \rho / 1000 p .
\end{gathered}
$$

The above equations indicate that the radon flux rate can be calculated when the parameters of $R, w, \rho$ and $E$ in the soil are known.

\section{Measurement results}

Three types of soil prevail in Vilnius city - sand, sandy loam and clay loam. The specific activity of natural radionuclides ${ }^{232} \mathrm{Th},{ }^{226} \mathrm{Ra}$ and ${ }^{40} \mathrm{~K}$ found in the soil, taking samples from different parts of Vilnius, was estimated. Statistical treatment of the specific activity of natural radionuclides in the soil is presented in Table 1.

It was identified that ${ }^{40} \mathrm{~K}$ had the highest measured specific activity out of all the studied radionuclides, its contribution to external equivalent dose rate was the largest. High correlation coefficients between the equivalent dose rate in the air layer close to the ground surface with the main ${ }^{40} \mathrm{~K}$ gamma emitters and ${ }^{226} \mathrm{Ra}$ specific activity in the soil (relatively 0,66 and 0,70 ) were identified. Meanwhile, low negative correlation $(-0,24)$ was noticed between the equivalent dose rate and the specific activity of ${ }^{232} \mathrm{Th}$ in the soil. Also, in 1992-1995 the specific activity in the soil of the main gamma emitters ${ }^{40} \mathrm{~K}$ and ${ }^{226} \mathrm{Ra}$ and the equivalent dose rate close to the ground surface above the sample location were measured, and, according to these results, it was identified that dose rate in the air layer close to the ground surface was mostly influenced by ${ }^{40} \mathrm{~K}$ found in the soil [19]. It was identified that external equivalent dose rate, influenced by radiation of the radionuclides present in the soil, formed 35-64\% out of the total equivalent dose rate in the air layer close to the ground surface, out of which ${ }^{40} \mathrm{~K}$ took a significant part (on an average $33 \%$ ); ${ }^{226} \mathrm{Ra}$ and its decay products made up $12 \%$ on an average, ${ }^{232} \mathrm{Th}$ and its decay products $-6 \%$ [20].

Due to a different soil composition and uneven amount of deposits, the quantities of natural radionuclides in the samples vary up to 3 times. Fig 2 illustrates the distribution of natural radionuclides ${ }^{232} \mathrm{Th},{ }^{226} \mathrm{Ra}$ and ${ }^{40} \mathrm{~K}$ in the studied soil samples [21].

The largest quantities of natural radionuclides were found in sand, but it also depended on the location a sample was taken from. We could not strictly distinguish the type of soil, which according to the quantity of natural radionuclides in it, is more or less active.

In the samples of sand the values of the specific activity of ${ }^{40} \mathrm{~K}$ vary in a wide range, from $479 \mathrm{~Bq} / \mathrm{kg}$ to $200 \mathrm{~Bq} / \mathrm{kg}$, what cannot be said about clay loam where the values vary merely by about $7,5 \%$ from the average.

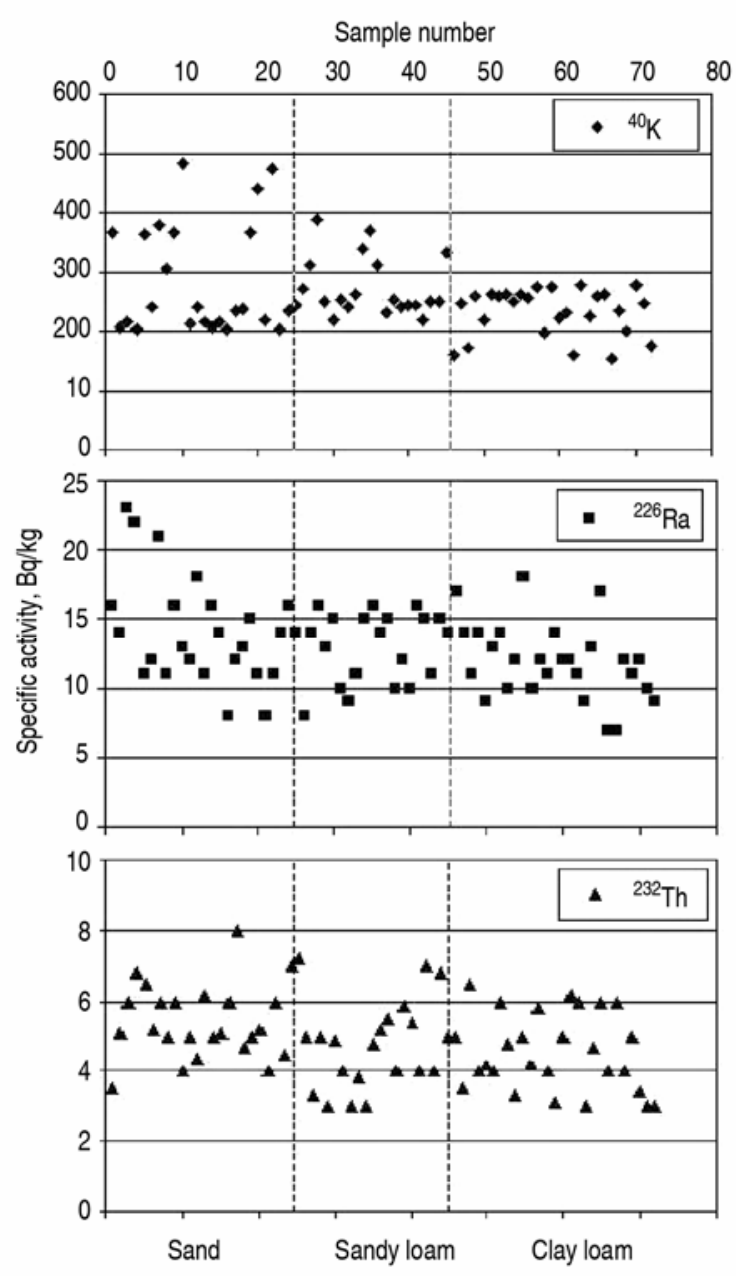

Fig 2. Specific activity of ${ }^{232} \mathrm{Th},{ }^{226} \mathrm{Ra}$ and ${ }^{40} \mathrm{~K}$ in soil samples of different granulemetric composition

Table 1. Specific activity of natural radionuclides in the soil of Vilnius city

\begin{tabular}{c|c|c|c|c|c}
\hline \multirow{2}{*}{ Radionuclide } & \multicolumn{4}{|c}{ Specific activity, Bq/kg } \\
\cline { 2 - 6 } & $\begin{array}{c}\text { Maximum } \\
\text { value }\end{array}$ & $\begin{array}{c}\text { Minimum } \\
\text { value }\end{array}$ & $\begin{array}{c}\text { Average } \\
\text { value }\end{array}$ & Median & Mean square deviation \\
\hline${ }^{232} \mathrm{Th}$ & 8,5 & 3,2 & 4,8 & 5,0 & $\pm 1,2$ \\
\hline${ }^{226} \mathrm{Ra}$ & 23,3 & 7,0 & 12,9 & 12,5 & $\pm 3,2$ \\
\hline${ }^{40} \mathrm{~K}$ & 479,3 & 146,1 & 263,1 & 245,5 & $\pm 67,4$ \\
\hline
\end{tabular}


Table 2. Specific activity of natural radionuclides in different types of soil

\begin{tabular}{|c|c|c|c|c|c|c|c|}
\hline \multirow{3}{*}{ Soil type } & \multirow{3}{*}{ Sample number } & \multicolumn{6}{|c|}{ Specific activity, $\mathrm{Bq} / \mathrm{kg}$} \\
\hline & & \multicolumn{2}{|c|}{${ }^{40} \mathrm{~K}$} & \multicolumn{2}{|c|}{${ }^{226} \mathrm{Ra}$} & \multicolumn{2}{|c|}{${ }^{232} \mathrm{Th}$} \\
\hline & & Average & $\begin{array}{l}\text { Standard } \\
\text { deviation }\end{array}$ & Average & $\begin{array}{l}\text { Standard } \\
\text { deviation }\end{array}$ & Average & $\begin{array}{r}\text { Standard } \\
\text { deviation }\end{array}$ \\
\hline Sand & 24 & 284,0 & $\pm 46,3$ & 14,2 & $\pm 2,5$ & 5,3 & $\pm 0,9$ \\
\hline Sandy loam & 21 & 272,1 & $\pm 22,2$ & 13,0 & $\pm 2,1$ & 4,6 & $\pm 0,5$ \\
\hline Clay loam & 27 & 232,0 & $\pm 17,3$ & 11,9 & $\pm 1,2$ & 4,4 & $\pm 0,4$ \\
\hline
\end{tabular}

Table 3. Average ${ }^{226} \mathrm{Ra}$ concentration and average ${ }^{222} \mathrm{Rn}$ exhalation rate with variation (minimum-maximum) in different types of soil

\begin{tabular}{c|c|c|c}
\hline Soil type & Number of samples & ${ }^{226} \mathrm{Ra} \mathrm{Bq} \mathrm{kg}^{-1}$ & ${ }^{222} \mathrm{Rn}$ exhalation rate $\mathrm{Bq} \mathrm{m}^{-2} \mathrm{~h}^{-1}$ \\
\hline Sand & 24 & 14,2 & $23,5(17,8-28,9)$ \\
\hline Sandy loam & 21 & 13,1 & $16,5(6,1-21,0)$ \\
\hline Clay loam & 27 & 11,9 & $14,5(4,2-25,5)$ \\
\hline
\end{tabular}

Higher values of ${ }^{40} \mathrm{~K}$ were identified in the eastsouthern and eastern parts of the city, smaller ones - in the northern and western parts.

The values of the specific activity of ${ }^{226} \mathrm{Ra}$ in the soil of Vilnius city vary similarly to ${ }^{40} \mathrm{~K}$, i e from 7 to $23 \mathrm{~Bq} / \mathrm{kg}$.

The specific activity of this radionuclide is larger in the southern and southeastern regions, its smallest values are in the central part of the city.

The values of the specific activity of ${ }^{208} \mathrm{Tl}$, a decay product of ${ }^{232} \mathrm{Th}$, range from 3 to $8 \mathrm{~Bq} / \mathrm{kg}$. They increase in the southern and southeastern parts, and the smallest measured values were identified in the central part of the city.

Table 2 presents a statistic treatment of the specific activity of the main gamma emitters in different types of soil.

The measured specific activity of natural radionuclide ${ }^{226} \mathrm{Ra}$ in the soil was compared with the results in various building materials (Fig 3 ). The specific activity of ${ }^{226} \mathrm{Ra}$ in building materials was measured using the previously mentioned methodology. It can be seen from the given data that the values of specific activity of this radionuclide in building materials varies from $1,9 \mathrm{~Bq} / \mathrm{kg}$ (in gypsum) to $52,7 \mathrm{~Bq} / \mathrm{kg}$ (in expanded clay).

The specific activity of the soil and widely used building materials differs in Lithuania and other countries. The specific activity of ${ }^{226} \mathrm{Ra}$ in cement used in India is about four times bigger than in Lithuania, the values of specific activity of ${ }^{226} \mathrm{Ra}$ in bricks used in Algeria and Germany are twice bigger than in Lithuania, the values of specific activity of ${ }^{226} \mathrm{Ra}$ in clay used in Germany are smaller than in Lithuania. It was determined that the specific activity of a natural radionuclide depends on the place of the extraction of a material.

Radon exhalation rate $(\mathrm{F})$ from the soil was calculated using radon exhalation rate from the material estimation model (Table 3).

The quantity of radium in a material is one of the most important parameters that determines the intensity of radon exhalation. The other parameters are porosity and chemical composition of a material.

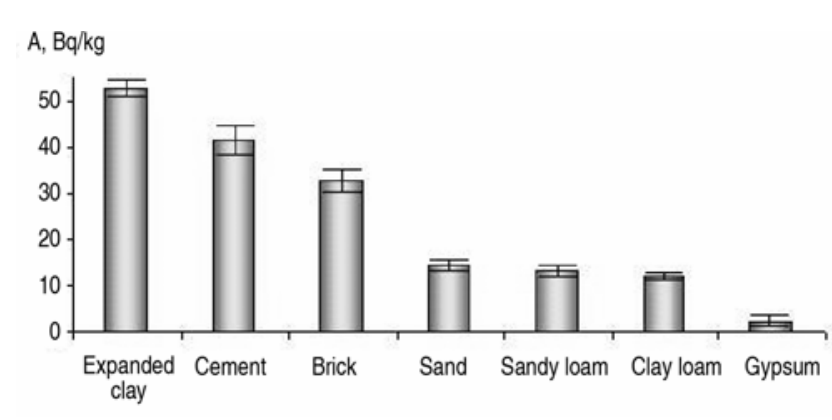

Fig 3. Specific activity of ${ }^{226} \mathrm{Ra}$ in soil samples of different granulemetric composition and in building materials

In Vilnius city a smaller radon exhalation rate from the soil was stated in the northern part. The biggest radon exhalation rate from the soil was stated in the southern and western parts of Vilnius city (Fig 4). Such quite a fair distribution of the values is determined by the type of the soil and its radioisotopic composition.

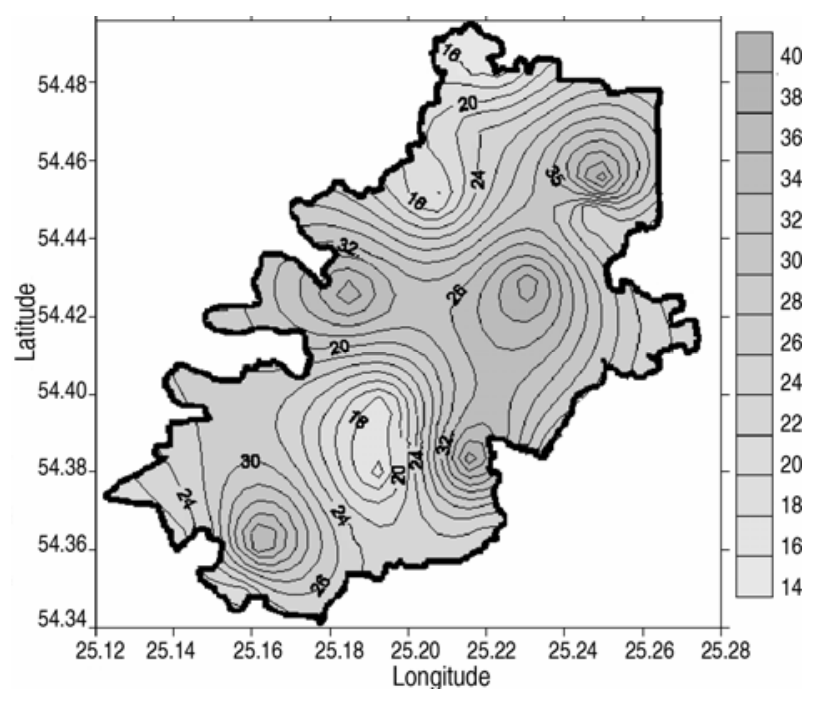

Fig 4. Distribution of radon exhalation rate from the soil in the territory of Vilnius city, $\mathrm{Bq} \mathrm{m}^{-2} \mathrm{~h}^{-1}$ 
${ }^{226} \mathrm{Ra}$ specific activity in building materials is bigger than in the soil, however, because of a smaller porosity of these materials (by up to $30 \%$ ) radon exhalation rate is smaller (Fig 5).

Though the quantity of radium in the soil is smaller, a bigger radon exhalation rate is determined by a bigger porosity of the soil (from $40 \%$ to $75 \%$ ). When materials are of a similar porosity, radon exhalation rate is determined by the quantity of radium in a material.

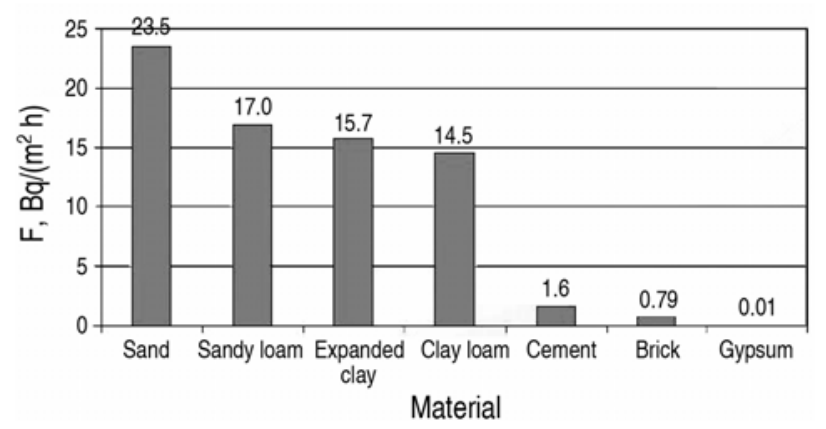

Fig 5. Radon exhalation rate (F) from the soil and building materials

Radon exhalation rate from the soil and widely used building materials in Lithuania and other countries differ a bit (Fig 6). It depends on the specific activity of ${ }^{226} \mathrm{Ra}$ in a material, its porosity as well as on the meteorological conditions and surface facing of a material.

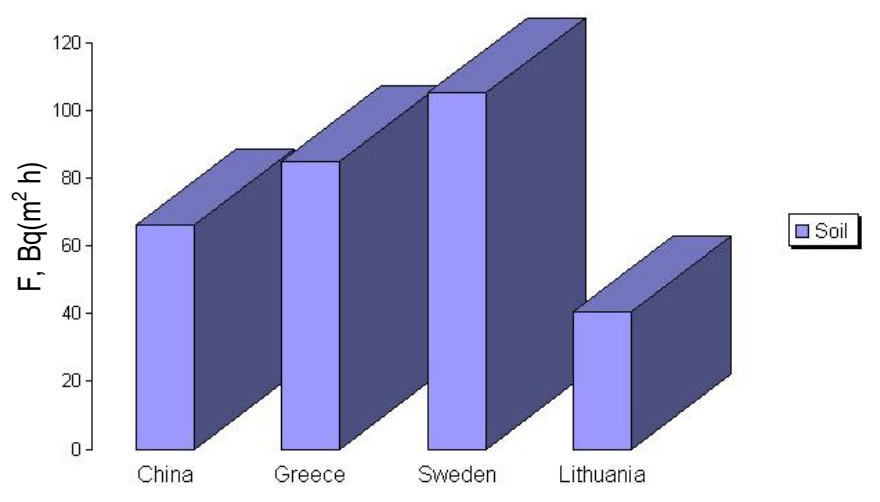

Fig 6. Radon exhalation rate from the soil in Lithuania and other countries

It is important to know the specific activity of ${ }^{226} \mathrm{Ra}$ in the soil and building materials because radon exhalation rate depends on it. For reducing the quantity of radon in an accommodation, some means of blocking radon exhalation from the soil (gap sealing and the like) and ventilation of the accommodation are needed. It is necessary to investigate and use emanation-blocking means for building materials (pore filling, surface coating by painting and the like). Also, properly chosen building materials, which have a smaller quantity of ${ }^{226} \mathrm{Ra}$, will reduce the volumetric activity of radon in an accommodation.

\section{Conclusions}

1. The specific activity of the main natural gamma emitters ${ }^{40} \mathrm{~K},{ }^{226} \mathrm{Ra}$ and ${ }^{232} \mathrm{Th}$ in different types of the soil in Vilnius city was measured. The largest values of ${ }^{40} \mathrm{~K}$ were identified in the southeastern and eastern parts of the city (sand and sandy loam prevail), the smallest ones - in the northern and western parts (sandy loam and clay loam prevail). The specific activity of ${ }^{226} \mathrm{Ra}$ is bigger in the southern and southeastern regions (sand and sandy loam prevail), the smallest values - in the central part of the city (clay loam prevails). The biggest values of the specific activity of ${ }^{232} \mathrm{Th}$ were in the southern and southeastern parts (sand and sandy loam prevail), and the smallest ones - in the central part (clay loam prevails).

2. Specific activity of natural radionuclide ${ }^{226} \mathrm{Ra}$ in the soil was compared to measured values in different building materials. Minimum ${ }^{226} \mathrm{Ra}$ is in gypsum $(1,9 \mathrm{~Bq} / \mathrm{kg})$, ten times more - in sand, clay and brick (about $20-30 \mathrm{~Bq} / \mathrm{kg}$ ), maximum - in expanded clay $(52,7 \mathrm{~Bq} / \mathrm{kg})$.

3. Radon exhalation rate from the soil was evaluated using the model which estimates radon exhalation rate from a material. Average values are about $23 \mathrm{~Bq} \mathrm{~m}^{-2} \mathrm{~h}^{-1}$ (in sand), $17 \mathrm{~Bq} \mathrm{~m}^{-2} \mathrm{~h}^{-1}$ (in sandy loam), $15 \mathrm{~Bq} \mathrm{~m}^{-2} \mathrm{~h}^{-1}$ (in clay loam). It is identified that one of the most important parameters, which determines radon exhalation rate, is the quantity of radium. The other parameters are the porosity and chemical composition of a material.

4. In Vilnius city the biggest radon exhalation rate from the soil was stated in the southern and western parts. A smaller radon exhalation rate from the soil was stated in the northern part. The type of the soil and its radioisotopic composition determines such a distribution of the values.

5. Radon exhalation rate from widely used building materials was evaluated. The values vary from $0,01 \mathrm{~Bq} \mathrm{~m} \mathrm{~h}^{-1}$ (in gypsum) to $15,7 \mathrm{~Bq} \mathrm{~m}^{-2} \mathrm{~h}^{-1}$ (in expanded clay). It was determined that radon exhalation rate from the soil was bigger than from building materials. This is because of a bigger porosity of the soil.

6. For reducing the quantity of radon in an accommodation, some means of blocking radon exhalation from the soil (gap sealing and the like) and ventilation of the accommodation are needed. It is necessary to investigate and use some emanation-blocking means for building materials (pore filling, surface coating by painting and the like). It is significant to know the specific activity of ${ }^{226} \mathrm{Ra}$ in the soil and building materials because radon exhalation rate depends on it.

\section{References}

1. MIAH, F. K.; ROY, S.; TOUHIDUZZAMIN, M. and ALAM, B. Distribution of radionuclides in soil samples in and around Dhaka city. Appl. Radiat. Isot, 1998, 49, p 133-137.

2. UNSCEAR. Report to the General Assembly. Annex B: Exposures from natural radiation sources. United Nations, New York, 2000, p 89-92. 
3. GIRGŽDYS, A.; ULEVIČIUS, V. The concentration of radon and its short-term decay products in the atmospheric environment. Health Physics (Atmosferos fizika). Vilnius, 1985, p 28-33 (in Lithuanian). ISSN 0135-1419.

4. EL-HUSSEIN, A.; MOHHAMED, A.; AHMED, A. Radon exhalation and ultrafine fraction of radon progeny in closed room air. Atmospheric Environment, 1999, 33(2), p 183-190.

5. MASTAUSKAS, A.; MORKŪNAS, G. Problem of indoor radon in Lithuania. Health Physics, 1996, 70(6), p 581-581.

6. LUBIN, J. H. Studies of radon and lung canser in North America and China. Radiation Protection Dosimetry, 2003, 104(4), p 315-319.

7. KELLER, G.; HOFFMANN, B.; FEIGENSPAN, T. Radon permeability and radon exhalation of building materials. The Science of Total Eenvironment, 2001, 272, p 85-89.

8. SWEDJEMARK, G. A. Recent Swedish experiences in radon control. Health Physics, 1990, 58, p 453-456.

9. ACKERS, J. G. Direct measurement of radon exhalation from surfaces. Radiat. Prot. Dosim., 1984, 7(1-4), p 199_ 201.

10. LEUNG, J. K. C.; TSO, M. Y. W.; HO, C. V. Behavior of ${ }^{222} \mathrm{Rn}$ and its progeny in high-rise building. Health Physics, 1998, 75(3), p 303-312.

11. ClaVENSJO, B.; AKERBLOM, G.; MORKŪNAS, G. Indoor radon (Radonas patalpose). Vilnius, $1999.126 \mathrm{p}$ (in Lithuanian).

12. NEDVECKAITE், T. Radiation protection in Lithuania (Radiacinè sauga Lietuvoje). Vilnius, 2004. 239 p (in Lithuanian).

13. AYCIK, G. A.; ERKAN, A. Radioactivity measurements of coal and ashes from coal-fired power plants in the southwestern part of Turkey. Journal of Environmental Radioactivity, 1997, 35, p 23-35.

14. KOJIMA, H. The exhalation rate of radon in the atmosphere and the influencing factors. In Proceedings of the 7th Tohwa University International Symposium, Fukuoka, Japan, 23-25 October, 1997, p E-240.

15. SCHERY, S. D. and WASIOLEK, M. A. Modeling radon flux from the earth's surface. In Proceedings the 7th Tohwa University International Symposium, Fukuoka, Japan, 23-25 October, 1997, p E-207.

16. SUN, K.; GUO, Q.; ZHUO, W. Feasibility for mapping radon exhalation rate from the soil in China. Journal of Nuclear Science and Technology, January 2004, 41(1), p 86-90.

17. ROGERS, V. C. and NIELSON, K. K. Multiphase radon generation and transport in porous materials. Health Physics, 1991, 60, p 807-815.

18. Soil Physics Research Group of ISSAS. Mensuration on soil physical properties. Scientific Publishing House, Beijing, China, 1978.

19. Lithuanian ecological stability in historic context (Lietuvos ekologinis tvarumas istoriniame kontekste). Vilnius, 1999 (in Lithuanian).

20. KONSTANTINOVA, M.; BUTKUS, D. Estimation of external equivalent dose rate due to gamma radiation of natural radionuclides in the soil (Natūralios kilmès gama spinduliu, esančiu dirvoje, sukeltos išorinès lygiavertès dozès galios ịvertinimas). Health sciences, 2003, 3, p 5054 (in Lithuanian).

21. PEČIULIENĖ, M.; JASAITIS, D.; GIRGŽDYS, A. Natural radionuclides in the soil of Vilnius city and assessment of their hazard. Geology, 2006, 55, p 9-14.

\section{GAMTINIŲ RADIONUKLIDŲ PASISKIRSTYMAS IR RADONO EKSHALIACIJOS IŠ DIRVOS GREITIS VILNIAUS MIESTE}

\section{Jasaitis, A. Girgždys}

S antrauka

Vilniaus miesto teritorijoje eksperimentais nustatyta skirtingo dirvožemio tipo radioizotopinè sudètis ir, remiantis šiais duomenimis, įvertintas radono ekshaliacijos iš dirvos intensyvumas. Išmatuoti gamtinių radionuklidų ${ }^{226} \mathrm{Ra},{ }^{232} \mathrm{Th}$ ir ${ }^{40} \mathrm{~K}$ savitieji aktyvumai. Iš identifikuotu gamtinių radionuklidų didžiausi kiekiai yra ${ }^{40} \mathrm{~K}-263 \mathrm{~Bq} / \mathrm{kg}$, mažiausi $-{ }^{232} \mathrm{Th}-$ $5 \mathrm{~Bq} / \mathrm{kg}$, vidutinès ${ }^{226} \mathrm{Ra}$ vertès siekè $13 \mathrm{~Bq} / \mathrm{kg}$. Apskaičiuotas bei ̨̇vertintas radono ekshaliacijos iš dirvos greitis Vilniaus mieste. Nustatytas radono ekshaliacijos greičio verčiu pasiskirstymas visoje miesto teritorijoje. Gautos vertės kinta nuo $15 \mathrm{~Bq} / \mathrm{m}^{2} \cdot \mathrm{h}$ (priemolyje) iki $23 \mathrm{~Bq} / \mathrm{m}^{2} \cdot \mathrm{h}$ (smèlyje). Nustatyta, kad vieni iš svarbiausių parametrų, lemiančių radono ekshaliacijos intensyvumą iš dirvos, yra radžio kiekis ir dirvos poretumas. Pastebèta, kad radono ekshaliacijos greitis iš dirvos yra daug didesnis nei iš statybinių medžiagų. Ši skirtumą lemia didesnis dirvos porètumas.

Reikšminiai žodžiai: gamtiniai radionuklidai, savitasis aktyvumas, radonas, ekshaliacijos greitis, tūrinis aktyvumas, alfa dalelès.

\section{РАСПРЕДЕЛЕНИЕ ЕСТЕСТВЕННЫХ РАДИОНУКЛИДОВ И СКОРОСТЬ ЭКСГАЛЯЦИИ РАДОНА ИЗ ПОЧВЫ В ГОРОДЕ ВИЛЬНЮСЕ}

\section{Д. Ясайтис, А. Гиргждис}

Р е $з$ ю м е

На территории города Вильнюса экспериментально установлен радиоизотопный состав почв различного типа и на основании этих данных определена интенсивность эксгаляции радона из почвы. Измерена удельная активность естественных радионуклидов ${ }^{226} \mathrm{Ra},{ }^{232} \mathrm{Th}$ и ${ }^{40} \mathrm{~K}$. Из идентифицированных природных радионуклидов наибольшие количества у ${ }^{40} \mathrm{~K}-263$ Бк/кг, наименьшие $\mathrm{y}{ }^{232} \mathrm{Th}-5$ Бк/кг, средние значения ${ }^{226} \mathrm{Ra}$ достигают 13 Бк/кг. В Вильнюсе рассчитана и определена скорость эксгаляции радона из почвы. Определено также распределение величин

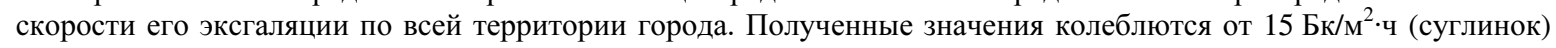


до 23 Бк/м²·ч (песок). Установлено, что одними из важнейших параметров, побуждающих интенсивность эксгаляции радона из почвы, являются количество радия и пористость почвы. Замечено, что интенсивность скорости эксгаляции радона из почвы значительно выше, чем из строительных материалов. Это различие обусловлено большей пористостью почвы.

Ключевые слова: естественные радионуклиды, удельная активность, радон, скорость эксгаляции, концентрация радона, альфа-частицы.

Dainius JASAITIS. Master, doctoral student, Dept of Physics, Vilnius Gediminas Technical University (VGTU).

Doctoral student (environmental engineering), VGTU, 2003. Master of Ecology, VGTU, 2002. Publications: co-author of 7 research papers. Research interests: environmental physics, natural radioactivity, ionizing radiation.

Aloyzas GIRGŽDYS. Dr, head of Laboratory of Nuclear Hydrophysics, Vilnius Gediminas Technical University (VGTU).

Doctor of Science (environmental physics), Moscow Institute of Atmospheric Physics, 1985. First degree in Physics, Vilnius University (VU), 1970. Publications: author of 1 monograph, over 170 research papers. Research interests: environmental physics, aerosol physics. 